\title{
Evaluation of the Compressive Strength of Ancient Clay Bricks Using Microdrilling
}

\author{
Francisco Fernandes ${ }^{1}$ and Paulo B. Lourenço ${ }^{2}$
}

\begin{abstract}
Nondestructive testing techniques are increasingly being used to obtain the geometry of structural and nonstructural elements and hidden features such as voids, cracks, and detachments. However, the evaluation of the compressive strength and other mechanical properties of ancient materials using such techniques remains a challenge. To reliably assess mechanical properties, it is usually necessary to directly test the strength and deformation of materials by destructive methods. To avoid coring and sampling of the historic fabric, a recent minor-destructive methodology based in microdrilling is used in this paper for the characterization of clay brick. For this purpose, 148 brick specimens from the 12th to 19th centuries were collected from six monasteries in Portugal. A wide range of compressive strength was found by destructive compressive testing, ranging from 6.7 to $21.8 \mathrm{~N} / \mathrm{mm}^{2}$. The paper shows that it is possible to reliably estimate the compressive strength of bricks by means of regression curves using the adopted microdrilling technique.
\end{abstract}

DOI: 10.1061/(ASCE)0899-1561(2007)19:9(791)

CE Database subject headings: Clays; Bricks; Compressive strength; Drilling.

\section{Introduction}

Conservation of architectural heritage is a difficult task due to the complex geometry of buildings and the large variability of the construction materials. The tasks of inspection and diagnosis of ancient buildings require obtaining a certain number of parameters, which provide information about the properties of the materials, the structural behavior, or possible defects. Mechanical characterization is a fundamental task for the structural works and safety assessment, where the compression strength is a key parameter in the case of masonry structures. In fact, the compressive strength of masonry in the direction normal to the bed joints has been traditionally regarded as the sole relevant structural material property, at least until the recent introduction of advanced numerical methods for masonry structures.

In the last decades, the strategic importance of ancient buildings due to cultural and economical reasons caused a large increase of the studies dealing with ancient structures and materials. In the case of ancient clay brick masonries, many studies have been focusing on the main mechanical properties (compressive strength and elastic modulus) and behavior of the composite material (Binda et al. 2000), retrofitting techniques (Binda et al. 1999), seismic vulnerability, physical and chemical deterioration, and pollution (Wijffels and Nijland 2004; Cultrone et al. 2000).

${ }^{1}$ Postdoctoral Researcher, Dept. of Civil Engineering, Univ. of Minho, Azurém, P-4800-058 Guimarães, Portugal. E-mail: fmcpf@civil. uminho.pt

${ }^{2}$ Professor, Dept. of Civil Engineering, Univ. of Minho, Azurém, P-4800-058 Guimarães, Portugal (corresponding author). E-mail: pbl@ civil.uminho.pt

Note. Associate Editor: Kolluru V. Subramaniam. Discussion open until February 1, 2008. Separate discussions must be submitted for individual papers. To extend the closing date by one month, a written request must be filed with the ASCE Managing Editor. The manuscript for this paper was submitted for review and possible publication on January 4, 2006; approved on June 27, 2006. This paper is part of the Journal of Materials in Civil Engineering, Vol. 19, No. 9, September 1, 2007. CASCE, ISSN 0899-1561/2007/9-791-800/\$25.00.
Studies related to ancient clay bricks alone deal mainly with physical, chemical, and mineralogical composition (López-Arce et al. 2003; Cardiano et al. 2004; Pauri et al. 1994), durability and deterioration agents (Wijffels and Nijland 2004) and deterioration modeling (Cultrone et al. 2000; Binda et al. 1996a, 1997), neglecting the mechanical properties. However, the mechanical properties of clay brick are very relevant as the resistance and durability of masonry depend greatly on the characteristics of the brick. Although its evidently important, only a few published studies focus on the mechanical properties of clay bricks (Papayianni and Stefanidou 2000; Baronio and Binda 1985) and on the process to reliably obtain those values.

Due to the high heterogeneity of clay bricks, it is very difficult to develop a general model to predict their mechanical properties. Some attempts were made to obtain mechanical information from other properties or by using nondestructive techniques. The compressive strength of clay bricks is usually related to other properties, such as porosity and firing temperature, which are key parameters for durability (Cultrone et al. 2000) but can markedly affect the mechanical resistance of bricks (Cultrone et al. 2004). The assessment of the compressive strength can be obtained in the laboratory through uniaxial compression tests (CEN 2000). But this requires the removal of samples from the buildings, which is not always possible and cannot be carried out in large scale for a given case study. Flat-jack testing is a very adequate in situ technique for the determination of the state of stress of the masonry or the masonry compressive strength, however it is not appropriate to characterize the compressive strength of masonry units alone and represents a costly investigation technique. A simple statistical approach was proposed in Barbi et al. (2002) to predict the mechanical properties of clay bricks but additional compression tests are required for confirmation and unacceptable results could be found using the proposed approach. Thus, in order to allow a rapid collection of reliable mechanical data, both for structural purposes and for identification of damaged/weak parts, a methodology based on the microdrilling technique is addressed here. The objective of this investigation is to establish a simple regression model to mechanically characterize ancient clay 
bricks to be used in current engineering applications. For this purpose, an extensive sample of old clay bricks and new handmade clay bricks from diverse sources has been collected and was systematically subjected to microdrilling and uniaxial compression tests. Compressive strength $\left(f_{c}\right)$ was obtained from the data that resulted from the compression tests in the laboratory while the drilling resistance $\left(\mathrm{DR}_{\sigma}\right)$ was determined from drillings made in companion brick specimens.

\section{Drilling Resistance Measurement System}

\section{General Description}

The drilling resistance measurement system (DRMS) has been developed as an attempt to obtain a portable system capable of carrying out minor-destructive tests in the laboratory and in situ based on microdrilling. The original objective was to measure continuously and reliably the superficial resistance ("hardness") and the in depth cohesional properties of natural stone. The equipment also aimed at determining the effectiveness of the treatments based on consolidants (Tiano 2001; Tiano et al. 2000a). Further information about the technical and scientific backgrounds involved can be found in Exadaktylos et al. (2000). In fact, other superficial methods, such as the Schmidt hammer, do not provide data on the strength variation in depth. The use of a minordestructive test (MDT) was considered thus necessary for obtaining reliable results related to cohesional properties. The DRMS makes it possible to obtain the drilling resistance based on the measurement of the force (in Newton, $\mathrm{N}$ ) and the torque (in $\mathrm{mN}$ $\mathrm{m})$ necessary to drill a hole under specific operative conditions (Exadaktylos et al. 2000).

The equipment available at the University of Minho was provided by SINT Technology, and consists of the followings components (Exadaktylos et al. 2000):

1. A mechanical device equipped with motors for positioning and drilling as well as force and torque load cells, with $500 \mathrm{~N}$ and $100 \mathrm{mN} \mathrm{m}$ of maximum capacity, respectively [Fig. 1(a)];

2. An electronic unit that contains the power unit, control boards for DC and stepper motors, signal amplifiers for load cells, computer for test procedure, graphic visualization, and data storage [Fig. 1(b)];

3. A tripod that can be adjusted in height from 830 to $1,600 \mathrm{~mm}$ with feet standing on a plane not larger than $900 \mathrm{~mm}$ in the drilling direction. The tripod feet can be fixed to the floor using nails and the head allows threedimensional movements in order to correctly position the drilling unit [Fig. 1(c)]; and

4. Additional parts: two steel plates with three threaded bars and lock nuts to hold specimens for laboratory testing [Fig. 2(a)], and three adjustable sharp-pointed screws to provide the support during in situ tests over regular and irregular surfaces [Figs. 2(b and c)].

The DRMS version used is fully customizable and can be set up in terms of rotational speed (RS), from 0 to 1200 RPM, and penetration rate (PR), from 0 to $20 \mathrm{~mm} / \mathrm{min}$ (SINT 2001b). The RS is maintained constant by an electronic controller in the electronic device. Moreover, the displacement of the drill bit is maintained at a constant speed though the use of a stepper motor that gives a resolution of $0.0025 \mathrm{~mm} / \mathrm{step}$. The drill can also be manually positioned by moving it forward and backward with the keyboard (SINT 2001a). In order to provide reliable and repeatable

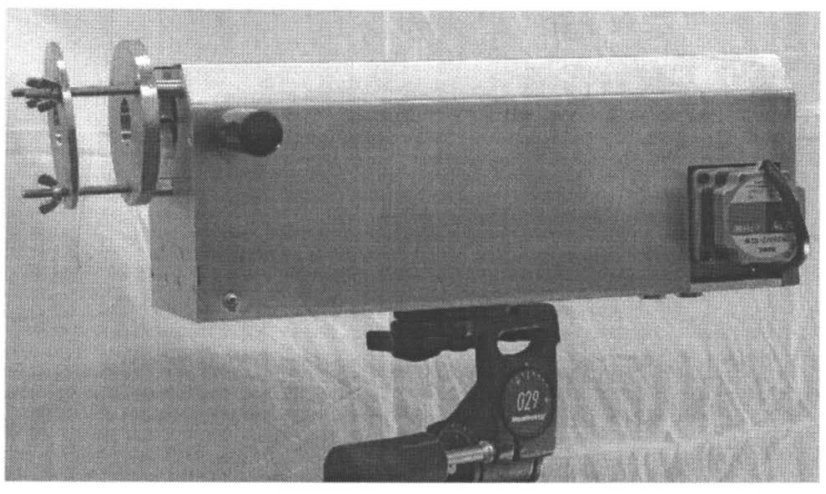

(a)

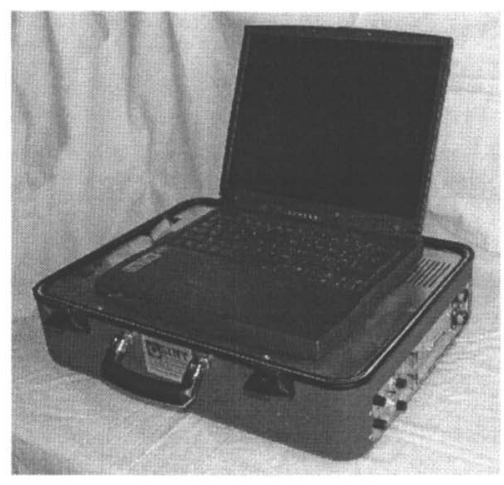

(b)

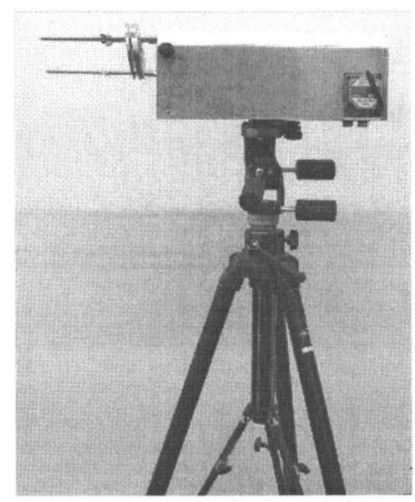

(c)

Fig. 1. Equipment for microdrilling: (a) mechanical device with drilling motor; (b) control unit with data visualization and storage; and (c) general view and three-dimensional tripod

results, specially made drill bits were used by soldering a polycrystalline diamond plaque on to the drill bit tip with two-lip end mill, with a diameter of $5 \mathrm{~mm}$ (Fig. 3) (Tiano et al. 2000b).

\section{Durability of Drill Bit}

The continuous drilling of old clay bricks that are constituted by abrasive elements such as sand grains and stone fragments causes, inevitably, the progressive wear of the diamond drill bit. Studies by Tiano et al. (2000b) showed that abrasive stones cause the drill bit to exhibit a much higher drilling force very early. This "virtual" increase is due to the wearing of the drill bit, which needs more effort to keep the same rotational and advancement speed. 


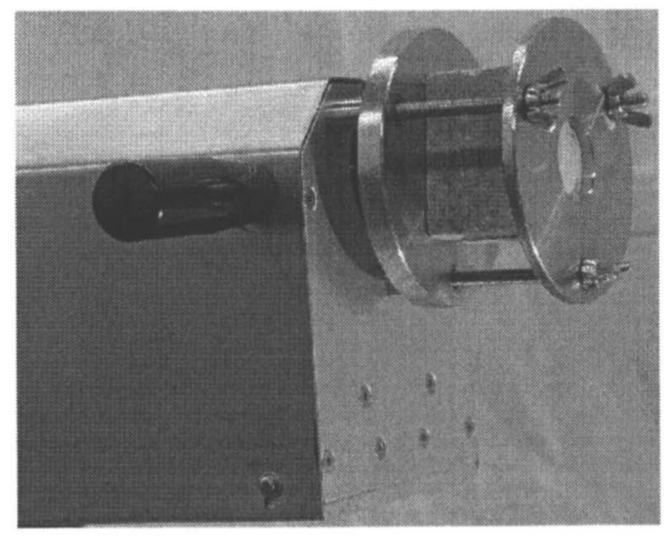

(a)

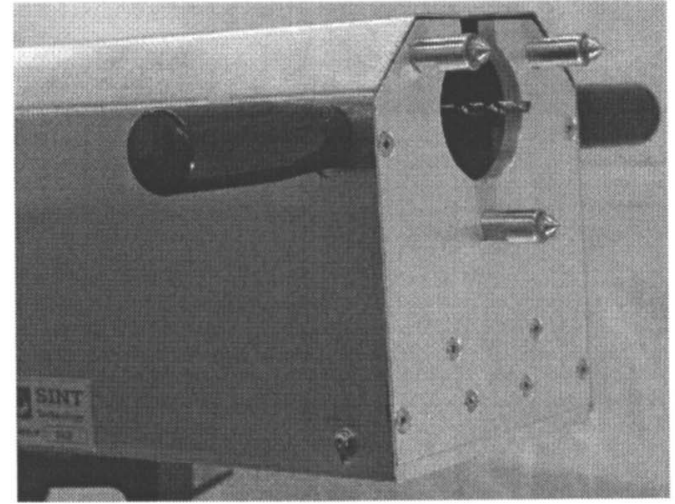

(b)

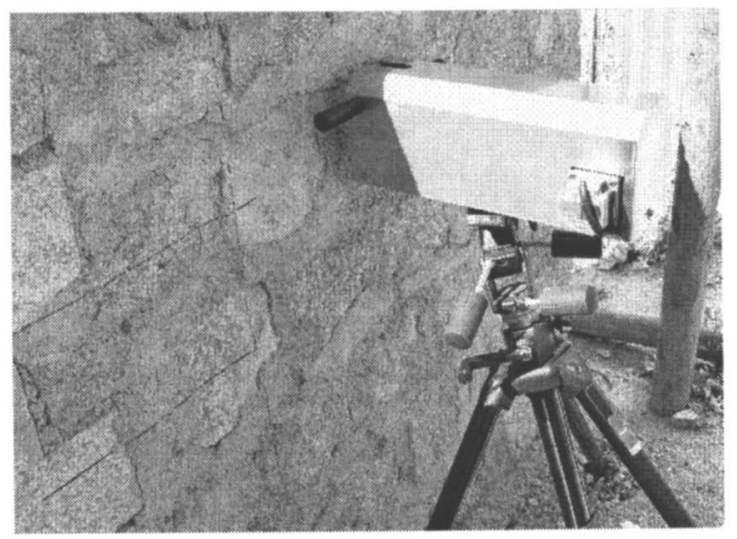

(c)

Fig. 2. Operation possibilities of DRMS equipment: (a) sample ready for testing, inside steel plates clamping system; and (b) view of three adjustable sharp-pointed screws for (c) in situ usage of equipment

In this study, the drill bits start to show wear after having made 30-40 holes. Due to the heterogeneous nature of old clay brick, a more precise indication cannot be given at this stage. It is noted that Delgado Rodrigues and Costa (2004) proposed a method to correct the progressive wear of the drill bit. This method is rather difficult to apply for very heterogeneous materials because a reference is needed to calculate the correction factors. Here, the wear of the drill bit was carefully monitored through regular drilling on a ceramic reference stone.
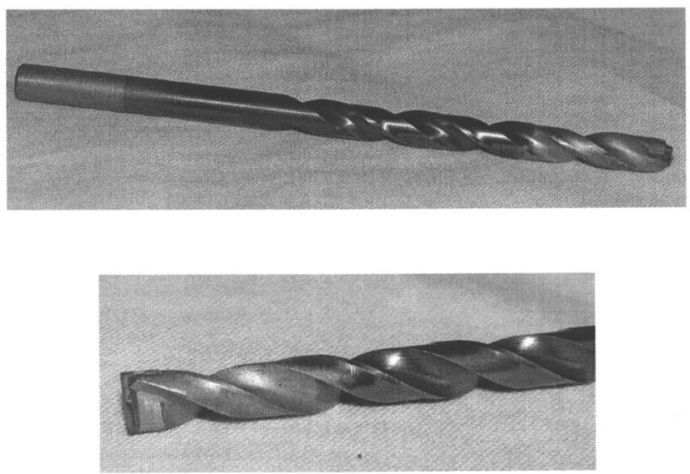

Fig. 3. Special DIABER (Italy) drill bit for use in microdrilling system with polycrystalline diamond plaque and two-lips end mill tip

\section{Description of Bricks' Sample and Testing Methodology}

The sample adopted in this study includes a large group of clay bricks collected from six different Portuguese national monuments, located all over the country and with rather different physical and mechanical properties (see Fig. 4). Table 1 reports a brief description of the sampled material in terms of acronym, number of specimens gathered, period, and origin, while Table 2 gives the dimensions and main physical properties of the brick specimens. The absorption of clay of both old and new bricks was based in the $24 \mathrm{~h}$ cold water submersion of the ASTM standard C67-98a. The porosity was calculated through hydrostatic weighing, described in the European Norm NP EN 772-3 (CEN 2000). Additional details on physical testing can be found in Fernandes (2006). The mechanical property retrieved from the test specimens was solely the peak compressive strength $f_{c}$, taking into account the methods suggested by ISRM for rock materials (ISRM 1978) and the ASTM standard C67-98a. Small specimens were cut from the old clay bricks available in the sample and some of them were tested in compression in order to obtain the corresponding strength, while the remaining specimens were tested with the microdrilling equipment.

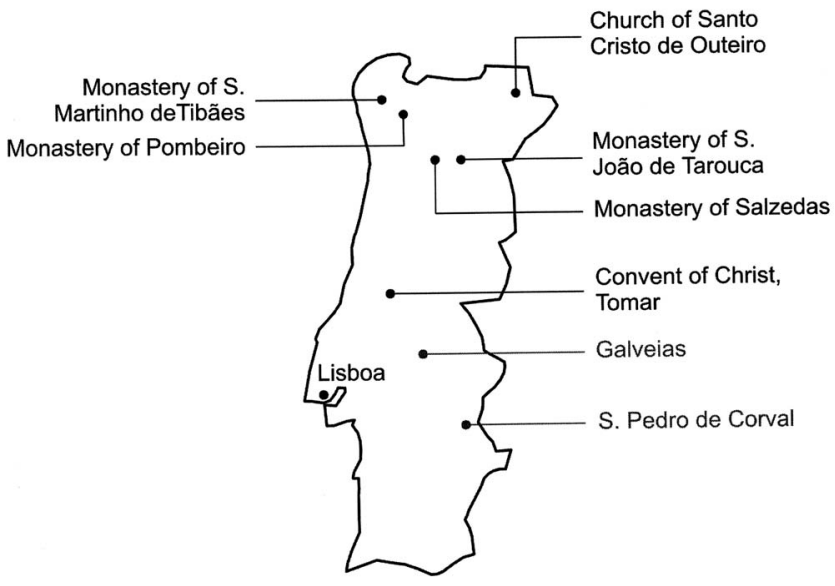

Fig. 4. Portuguese map showing location of six monuments where sample was collected 
Table 1. Description of Origin and Number of Specimens of Sampled Material

\begin{tabular}{lccc}
\hline Monument & $\begin{array}{c}\text { Acronym } \\
\text { (number of specimens) }\end{array}$ & $\begin{array}{c}\text { Period } \\
\text { (century) }\end{array}$ & Origin \\
\hline Church of Santo Cristo de Outeiro & OU (10) & 17 & Outeiro, Bragança \\
Monastery of Pombeiro & PO (34) & $12-16$ & Pombeiro, Felgueiras \\
Monastery of Salzedas & SA (27) & $18-19$ & Salzedas, Tarouca \\
Monastery of S. João de Tarouca & TA (28) & $12-17$ & S. João de Tarouca, Tarouca \\
Monastery of S. Martinho de Tibães & TI (33) & Mire de Tibães, Braga \\
Convent of Christ & TO (16) & Tomar \\
\hline
\end{tabular}

\section{Compression Testing Procedure}

For the compression test, the specimens were cut from the bricks to be tested in the direction of the molding or perpendicular to bed joints (see Fig. 5), which is the usual loading direction in masonry elements (e.g., walls and vaults) subjected to dead load. Generally, very small specimens were obtained, with typical cross sections of $30 \times 30 \mathrm{~mm}^{2}$ and $30-40 \mathrm{~mm}$ of height. All specimens were ground using a rectifying machine, so that the loading faces were properly aligned. Due to the heterogeneity of the samples and the small height of the bricks, it was not possible to obtain specimens with a height/width ratio adequate to neglect the boundary effects (the height/width ratio should be larger than 2) (Neville 1963) and the presence of inclusions/voids (specimen size to inclusions/voids ratio should be larger than 10) (Fairhurst and Hudson 1999). Here, the smallest dimension accepted for testing after surface rectification was $20 \mathrm{~mm}$, as suggested in Binda et al. (1996b). This criterion resulted in the rejection of some specimens because the minimum dimension was not met or the distortion was so large that it was impossible to obtain a regular specimen for testing. Additionally, in order to minimize the effect of the friction effects imposed on the specimen by the machine platens, which have $100 \mathrm{~mm}$ of diameter, and in order to secure a uniform stress distribution at least in the center of the specimen, a pair of friction-reducing Teflon sheets with a thin layer of mineral oil in between was placed between the surfaces of the platens and the specimen (Fig. 6) (Binda et al. 1996b; Van Mier 1984, Van Vliet and Van Mier 1996).

The test setup for the compression tests is composed of a steel frame equipped with a compression load cell with a maximum capacity of $25 \mathrm{kN}$ and connected to an appropriate control system (see Fig. 7). The steel platens were rectified in order to provide a flat surface. The lower platen has a spherical seat made of tempered steel that allows the initial alignment and accommodation of the specimen, thus facilitating the alignment of the applied load with the center of the specimen as well as preventing any other unfavorable effect due to geometrical imperfection of the specimen. Finally, a steel cube with $100 \times 100 \times 100 \mathrm{~mm}^{3}$ provided additional height for the specimens. Because of the rather small dimensions of the brick specimens, besides the control displace- ment transducer, no displacement measuring device was mounted in the system. The variable selected as the feedback signal was the vertical displacement of the actuator, provided by an external linear variable displacement transducer (LVDT) with a linear field of $2.5 \mathrm{~mm}$, mounted in the actuator body. The test procedure started in load control until the specimen was loaded with a force of $0.25 \mathrm{kN}$. Then, the procedure was carried out entirely under displacement control by means of the vertical LVDT at a rate of loading in compression of $0.003 \mathrm{~mm} / \mathrm{s}$. The compressive strength $f_{c}$ of the test specimens was calculated by dividing the maximum compressive load on the specimen by the initial cross-sectional area.

\section{Microdrilling Testing Procedure}

For the microdrilling measurements, the specimens were fixed between the steel plates of the special equipment part [Figure 2(a)]. In order to adopt the most suitable operative conditions, an investigation through the available literature (Tiano et al. 2000b) concluded that the test parameters are essentially material dependent and that low penetration rates and rotational speeds increase the returned thrust and torque. Old clay bricks are mainly constituted by soft material (clay mass) but the presence of hard and highly abrasive sand grains and stone fragments require us to choose values for PR and RS to take into account the low resistance of the clay mass but to avoid out of scale values for harder elements. Thus, from preliminary experiments, the system parameters were fixed as: $P R=10 \mathrm{~mm} / \mathrm{min}$ and $\mathrm{RS}=600 \mathrm{rmp}$. Usually, in typical old masonry elements, the brick units are laid down in the direction of the bed surface and the only visible and accessible surfaces are the ones shown in Fig. 8. Therefore, drilling was carried out in the accessible surfaces, preferentially located in the central area of the specimen in order to avoid any possible border effects.

The procedure of comparing laboratory specimens' properties in one direction with in situ measurements in the orthogonal direction is obviously necessary for practical purposes, which is usual in anisotropic materials such as timber (see, e.g., Lourenço et al. 2006). Here, it is noted that Bati and Ranocchiai (1994),

Table 2. Dimensions, Physical Properties, and Compressive Strength from Brick Specimens (Number of Specimens Used between Brackets)

\begin{tabular}{|c|c|c|c|c|c|c|c|}
\hline Acronym & $\begin{array}{l}\text { Length } \\
(\mathrm{mm})\end{array}$ & $\begin{array}{l}\text { Width } \\
(\mathrm{mm})\end{array}$ & $\begin{array}{l}\text { Height } \\
(\mathrm{mm})\end{array}$ & $\begin{array}{l}\text { Bulk weight } \\
\left(\mathrm{kg} / \mathrm{m}^{3}\right)\end{array}$ & $\begin{array}{c}24 \mathrm{~h} \text { cold water absorption } \\
(\%)\end{array}$ & $\begin{array}{l}\text { Porosity } \\
(\%)\end{array}$ & $\begin{array}{l}\text { Compressive strength } \\
\left(\mathrm{N} / \mathrm{mm}^{2}\right)\end{array}$ \\
\hline OU (9) & $125-155$ & $85-125$ & $35-45$ & 1,800 & 17.6 & 28.2 & 8.5 \\
\hline PO (34) & $80-240$ & $110-140$ & $25-50$ & 1,742 & 19.9 & 31.8 & 9.2 \\
\hline SA (27) & $240-270$ & $125-155$ & $30-40$ & 1,739 & 18.8 & 30.4 & 14.5 \\
\hline TA (25) & $90-220$ & $80-125$ & $35-45$ & 1,754 & 15.8 & 26.3 & 8.7 \\
\hline TI (33) & $160-250$ & $90-190$ & $25-45$ & 1,747 & 17.8 & 29.2 & 6.7 \\
\hline TO (16) & $230-270$ & $110-140$ & $30-50$ & 1,656 & 15.0 & 27.5 & 21.8 \\
\hline
\end{tabular}




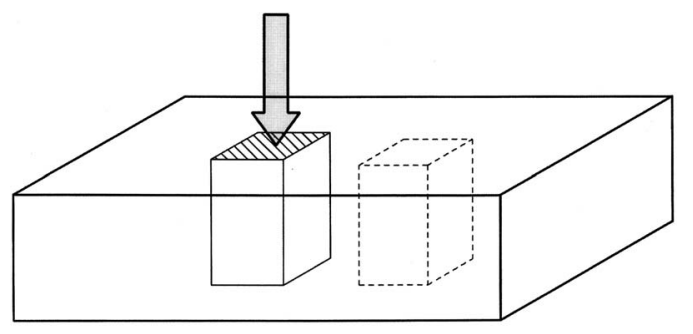

Fig. 5. Schematics showing how specimens were cut from bricks and direction of compression tests

Binda et al. (1996b), and Lourenço et al. (2005) found the greatest strength of modern bricks in the bed joint direction, due to the extrusion process. In Lourenço et al. (2005), the strength ratio between bed joint direction and head joint direction was between 1.2 and 1.5. It is noted that for ancient bricks a much smaller difference is expected due to the production process (hand molding) and that the largest strength is likely to occur in the vertical direction.

The drilled length was fixed to $20 \mathrm{~mm}$ in all specimens, as this is the minimum specimen size and average results are needed. The value used to characterize the microdrilling resistance is the drilling force divided by the cross section of the drill bit, $\mathrm{DR}_{\sigma}$. This has the advantage of providing a stress value, meaning that the influence of the drill diameter is removed. In addition, nondimensional correlations can be obtained with the compressive strength $f_{c}$. The presence of high strength inclusions such as sand grains or stone fragments with appreciable dimensions inside the brick specimens (in some cases larger than $5 \mathrm{~mm}$ ) and the presence of voids and cracks affects severely the average drilling resistance of bricks in the same way they can influence the compressive strength (Fairhurst and Hudson 1999). However, the contribution of these local defects in the behavior of the whole brick is less relevant. Fig. 9 illustrates the result of drilling through a stone fragment, while Fig. 10 illustrates the result of drilling through a crack in the interior of the brick. In both cases, rather homogeneous resistance profiles with moderate irregularities due to the microstructure of brick are observed (in solid line) together with one profile showing the influence of the anomalies previously described (in dashed line). These anomalies influence the final average drilling resistance of the specimen, and must be removed. As an example, the average drilling resistance of the profile $\mathrm{DR}_{\sigma}$ that crossed the stone fragment (Fig. 9) is $80 \%$ higher than the average of the remaining profiles, while in the case of the profile crossing an internal crack (Fig. 10), its drilling resistance $\mathrm{DR}_{\sigma}$ decreased $20 \%$ relative to the other profiles. Thus, in order

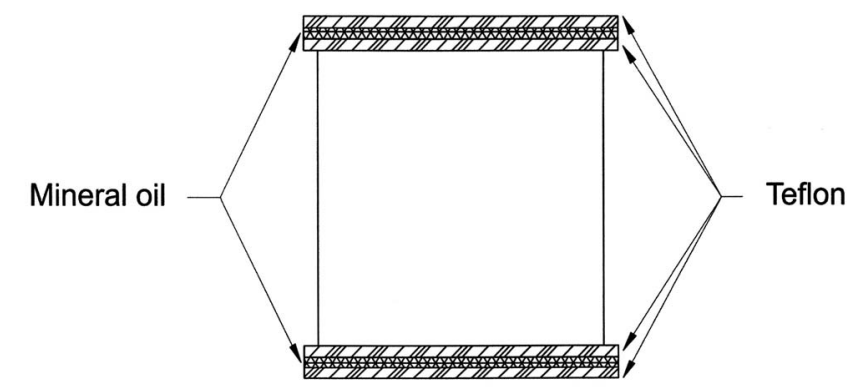

Fig. 6. Schematics showing way specimen was conditioned between machine platens

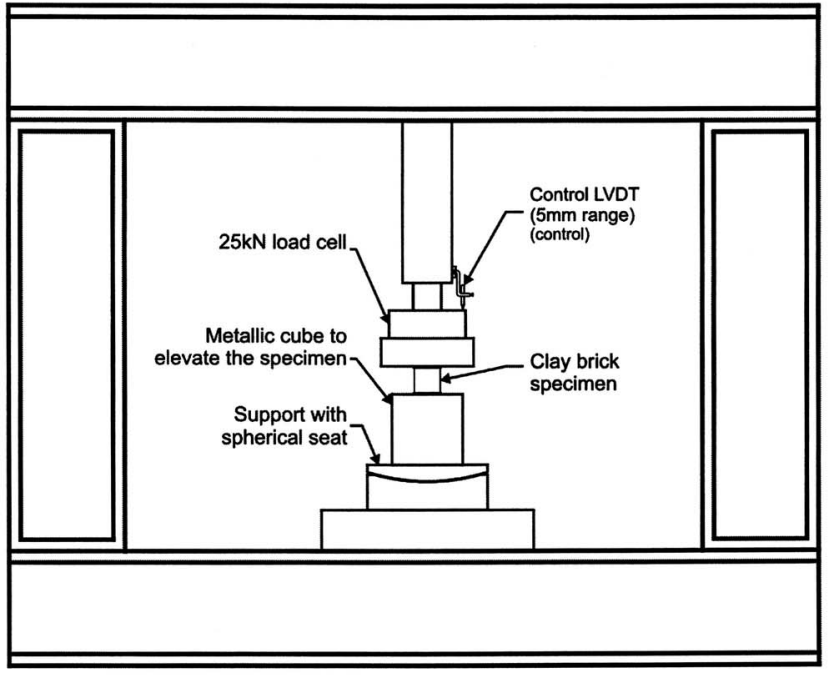

(a)

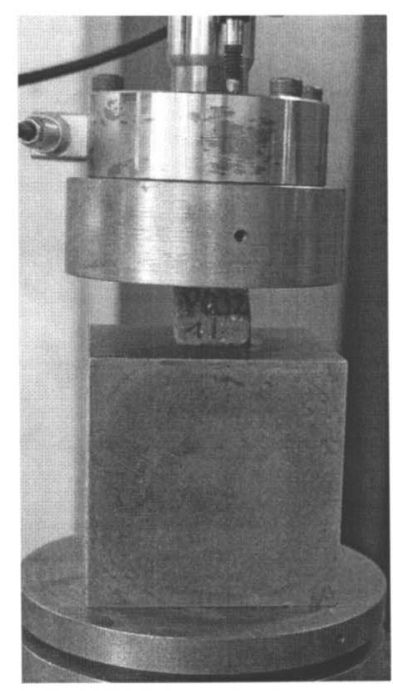

(b)

Fig. 7. Steel frame equipped with $25 \mathrm{kN}$ load cell for compression tests on brick specimens: (a) general view; (b) detail of specimen and load cell

to reduce the scatter and the influence of local defects as well as to define appropriately the characteristic drilling resistance average value, the procedure described next was used. Three to five holes were carried out in each specimen, taking into account its size and the difference in results between consecutive measurements. Holes were drilled in the middle of each specimen, and

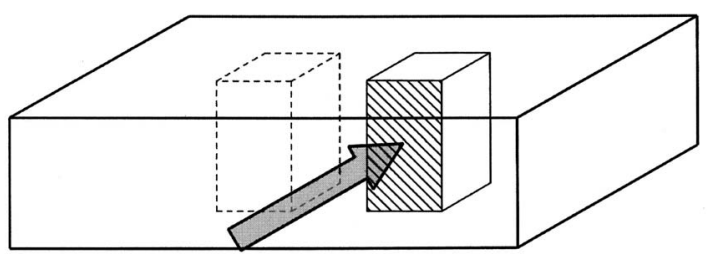

Fig. 8. Schematic showing surface considered for microdrilling measurements as well as direction of drilling, parallel to bed surface of bricks 


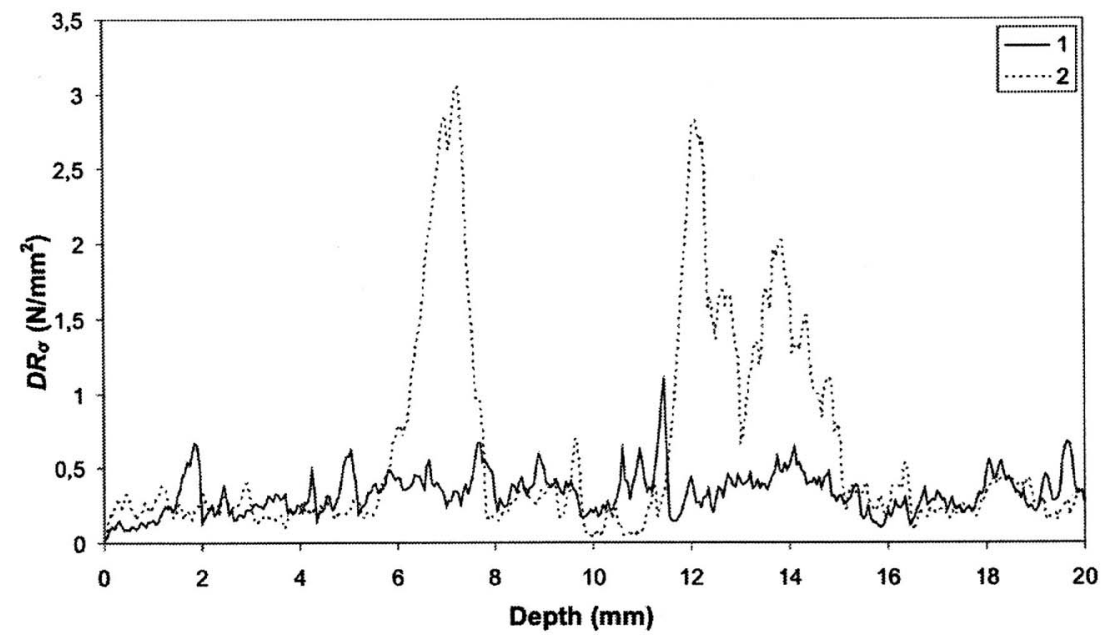

Location of the DRMS profiles

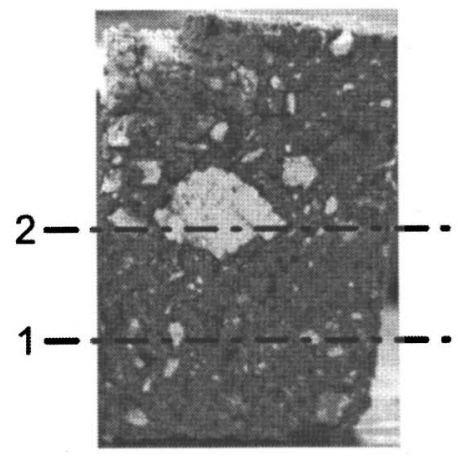

Fig. 9. Example of drilling resistance measurement through stone fragment, where curves 1 and 2 correspond to drilling positions 1 and 2 as shown in photograph on right

separated by a minimum distance of $10 \mathrm{~mm}$ (equivalent to two diameters of the drill bit) in order to avoid any effect induced by the specimen edges and previous holes. Low strength dips and high strength peaks were systematically removed. As an example, Fig. 11 shows the portion of data removed from the profile as well as the data used to calculate the average drilling resistance.

\section{Discussion of Results}

\section{Results for Compressive Strength}

Fig. 12 illustrates the average compressive strength $f_{c}$ for the complete sample as well as the dispersion of the data according to the origin. The number of specimens considered for testing in each group was: OU (8), PO (28), SA (27), TA (18), TI (23), and TO (16). The wide range of average strength found is between 6.7 and $21.8 \mathrm{~N} / \mathrm{mm}^{2}$. In particular, the strength of bricks from Tomar (TO) and Salzedas (SA) differ significantly from the other four groups of bricks. Their higher compressive strength seems to be related to the technological process available at the time of manufacture, as the bricks from Tomar (TO) and Salzedas (SA) are more recent than the other bricks. Additionally, sampling of the bricks comes from different locations. Clay bricks from Outeiro (OU), Pombeiro (PO), Tarouca (TA), and Tibães (TI) were collected from vaults, buried remainings, soil deposits, and infill material, while the clay bricks from Tomar (TO) and Salzedas (SA) were obtained from building elements. Therefore, environmental actions and deterioration can also contribute to the results obtained. Nevertheless, it is possible to observe that the bricks with lower $f_{c}$ also exhibit a higher dispersion, with coefficients of variation $(\mathrm{COV})$ up to 40 and $50 \%$. This indicates a very large variability of the compressive strength.

\section{Results for Drilling Measurements}

Fig. 13 illustrates the average drilling resistance $\mathrm{DR}_{\sigma}$ in $\mathrm{N} / \mathrm{mm}^{2}$ for the complete sample. The dispersion of the data per groups and the number of specimens considered for testing is also pro-

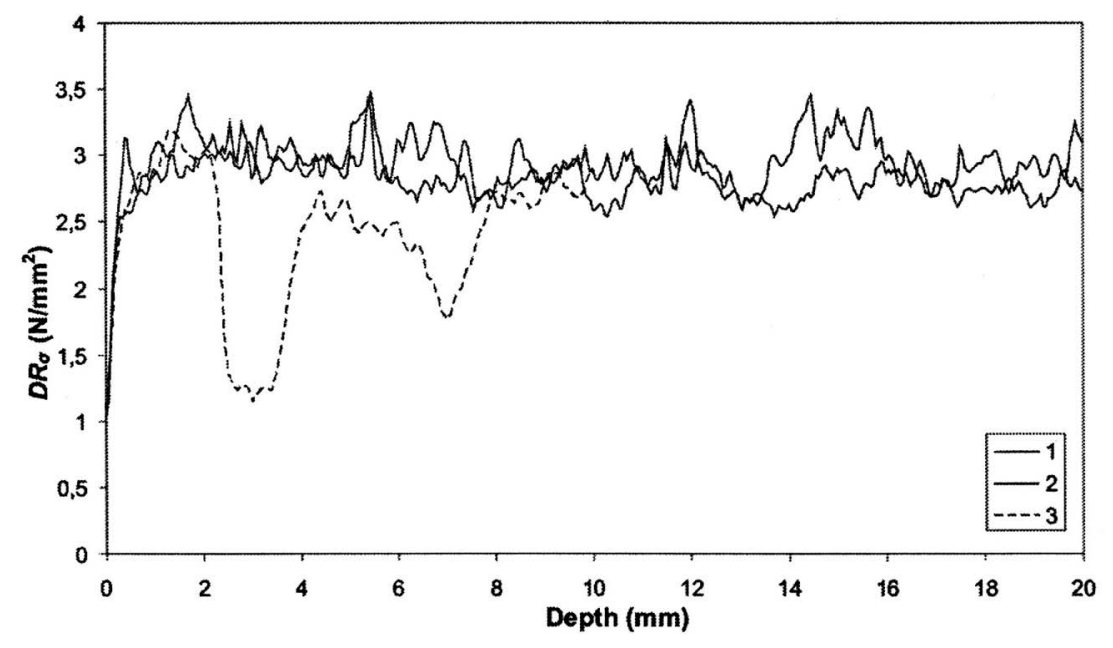

\section{Location of the DRMS profiles}

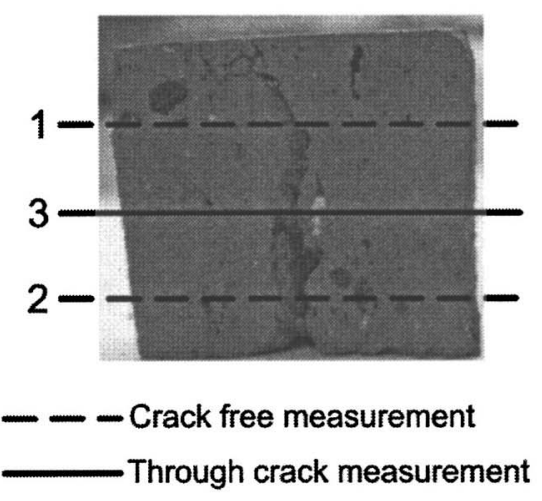

Fig. 10. Example of drilling resistance measurement through internal crack, where curves $1-3$ correspond to drilling positions $1-3$ as shown in photograph on right 


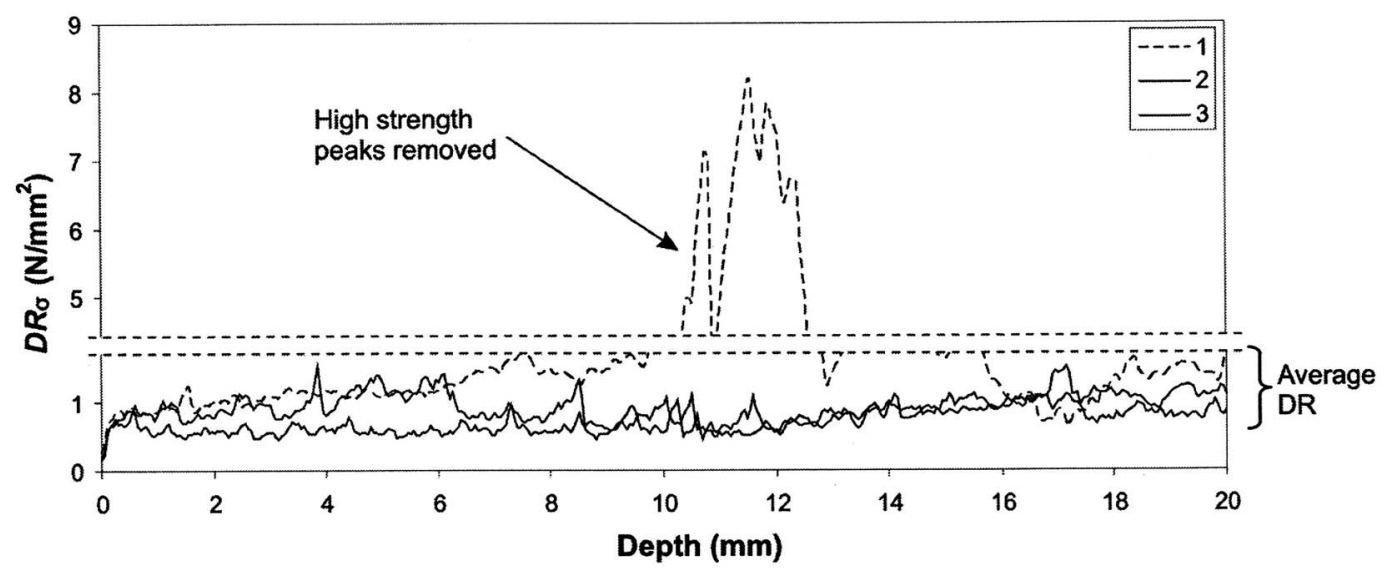

Fig. 11. Typical example of calculation of average DR $\sigma$

vided. The number of specimens in each group was: OU (9), PO (33), SA (27), TA (24), TI (29), and TO (15), and is different from the number considered in the compression tests because some specimens were adequate for microdrilling but inadequate for compression. The results of the drilling resistance are in agreement with the compressive strength results. However, the scatter found is even larger, with coefficients of variation up to nearly $100 \%$.

\section{Correlation between Compressive Strength and Drilling Resistance}

Regarding the correlation between the drilling resistance and the compressive strength, the complete results of all test specimens are shown in Fig. 14. A linear fit with the following equation: $f_{c}=5.328+3.959 \mathrm{DR}_{\sigma}$, provides an average value for $R^{2}(0.67)$. However, for lower values of $\mathrm{DR}_{\sigma}$, especially below $1 \mathrm{~N} / \mathrm{mm}^{2}$, the linear model gives too high and clearly erroneous values. Thus, a nonlinear fit was computed, and the best result was obtained with a power curve with the following equation: $f_{c}$ $=9.196 \mathrm{DR}_{\sigma}^{0.609}$, which provided a slightly higher $R^{2}(0.74)$. This result is in line with other studies that proposed a power law to correlate the compressive strength of old clay bricks from ultrasonic pulse velocity and Schmidt hammer rebound tests (Kirka and Erdem 2005). Both regression lines are reported over the complete dataset in Fig. 14. In the range between 10 and

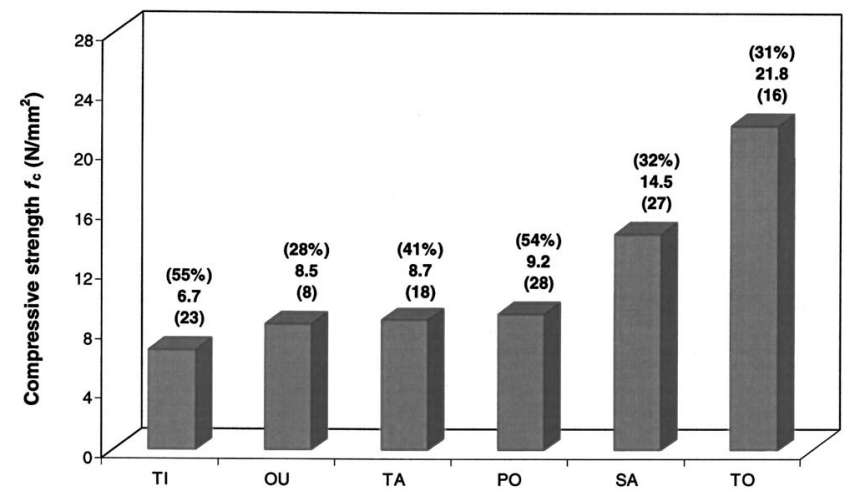

Fig. 12. Average compressive strength $f_{c}$, with coefficient of variation in percentage (above) and number of specimens (below)
$25 \mathrm{~N} / \mathrm{mm}^{2}$ for $f_{c}$ or between 1 and $5 \mathrm{~N} / \mathrm{mm}^{2}$ for $\mathrm{DR}_{\sigma}$, the difference between the two models seems to be rather low and, thus, both models are satisfactory. It is recommended to use the power law, up to a $\mathrm{DR}_{\sigma}$ value of $5 \mathrm{~N} / \mathrm{mm}^{2}$. After this value, the amount of experimental data is insufficient to provide any suggestion.

A $95 \%$ confidence interval is usually adopted in standards to include the statistical variation of the mechanical properties. Fig. 15 presents the lower confidence curve that can be used to provide a lower bound estimation $\left(f_{c}=4.870 \mathrm{DR}_{\sigma}^{0.609}\right)$ up to a $\mathrm{DR}_{\sigma}$ value of $3 \mathrm{~N} / \mathrm{mm}^{2}$. For higher values of $\mathrm{DR}_{\sigma}$ and $f_{c}$, the slope of the linear law should be adopted instead as the power law is too conservative.

\section{Validation of Models for New Handmade Clay Bricks}

Although the models fit conveniently the data from old clay bricks, it is considered of relevance to confirm the appropriateness of these models with different brick materials, especially bricks to be adopted as replacing material. For this purpose, modern handmade traditionally fired clay bricks were used, obtained from two different manufacturers from the region of Alentejo, in the South of Portugal, and often adopted as replacement material for old bricks. The two manufacturers are from the towns of Galveias (GA) and São Pedro de Corval (PC). The main physical properties as well as the average compressive strength of these bricks are presented in Table 3 . It can be observed that the spe-

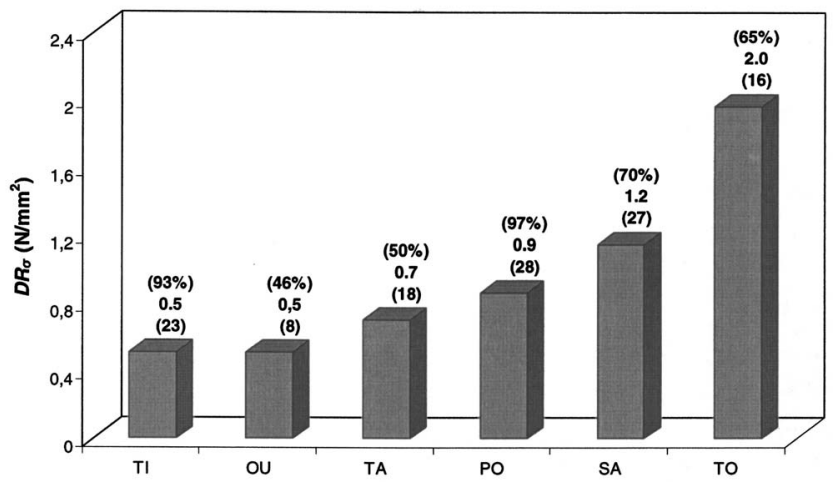

Fig. 13. Average drilling resistance $\mathrm{DR} \sigma$, with coefficient of variation in percentage (above) and number of specimens (below) 


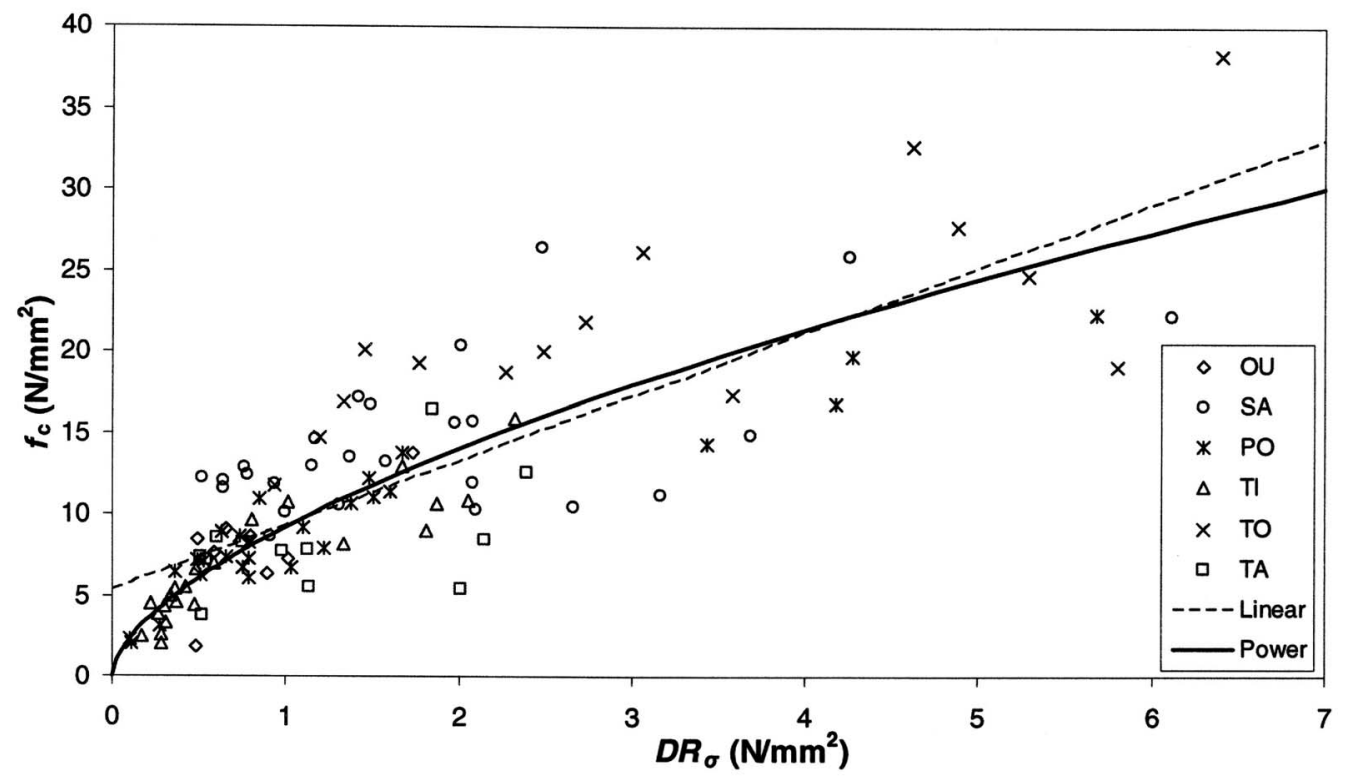

Fig. 14. Linear and nonlinear correlations between compressive strength $f_{c}$ and drilling resistance stress DR $\sigma$ for entire sample

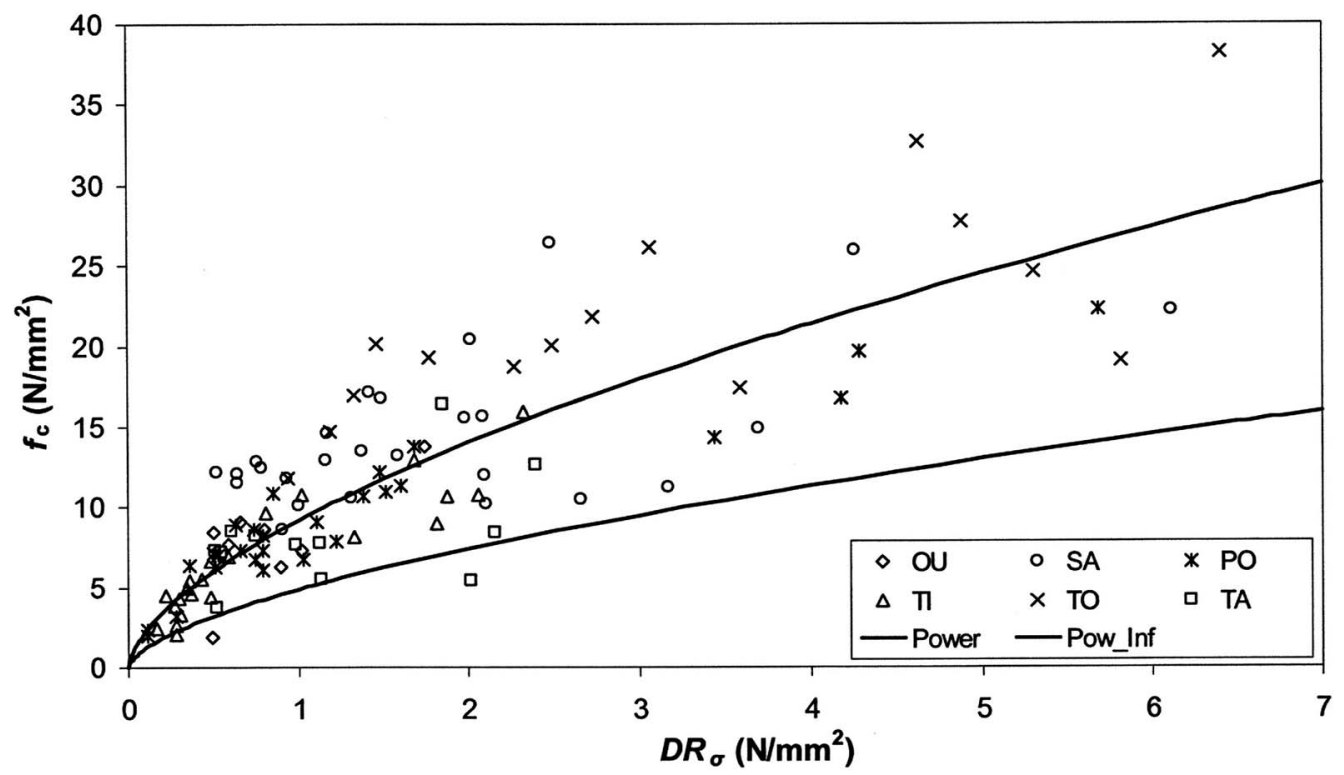

Fig. 15. Nonlinear correlation and lower limit for confidence interval of $95 \%$ between compressive strength $f_{c}$ and drilling resistance stress DR $\sigma$ for entire sample

Table 3. Physical Properties and Compressive Strength of New Handmade Brick's Sample

\begin{tabular}{|c|c|c|c|c|}
\hline Producer & $\begin{array}{l}\text { Bulk weight } \\
\left(\mathrm{kg} / \mathrm{m}^{3}\right)\end{array}$ & $\begin{array}{l}24 \text { h cold water } \\
\text { absorption } \\
(\%)\end{array}$ & $\begin{array}{l}\text { Porosity } \\
(\%)\end{array}$ & $\begin{array}{c}\text { Compressive strength } f_{c} \\
\left(\mathrm{~N} / \mathrm{mm}^{2}\right)\end{array}$ \\
\hline Galveias (GA) & 1,735 & 11.2 & 20.9 & 9.2 \\
\hline S. Pedro de Corval (PC) & 1,752 & 10.7 & 19.9 & 6.0 \\
\hline
\end{tabular}




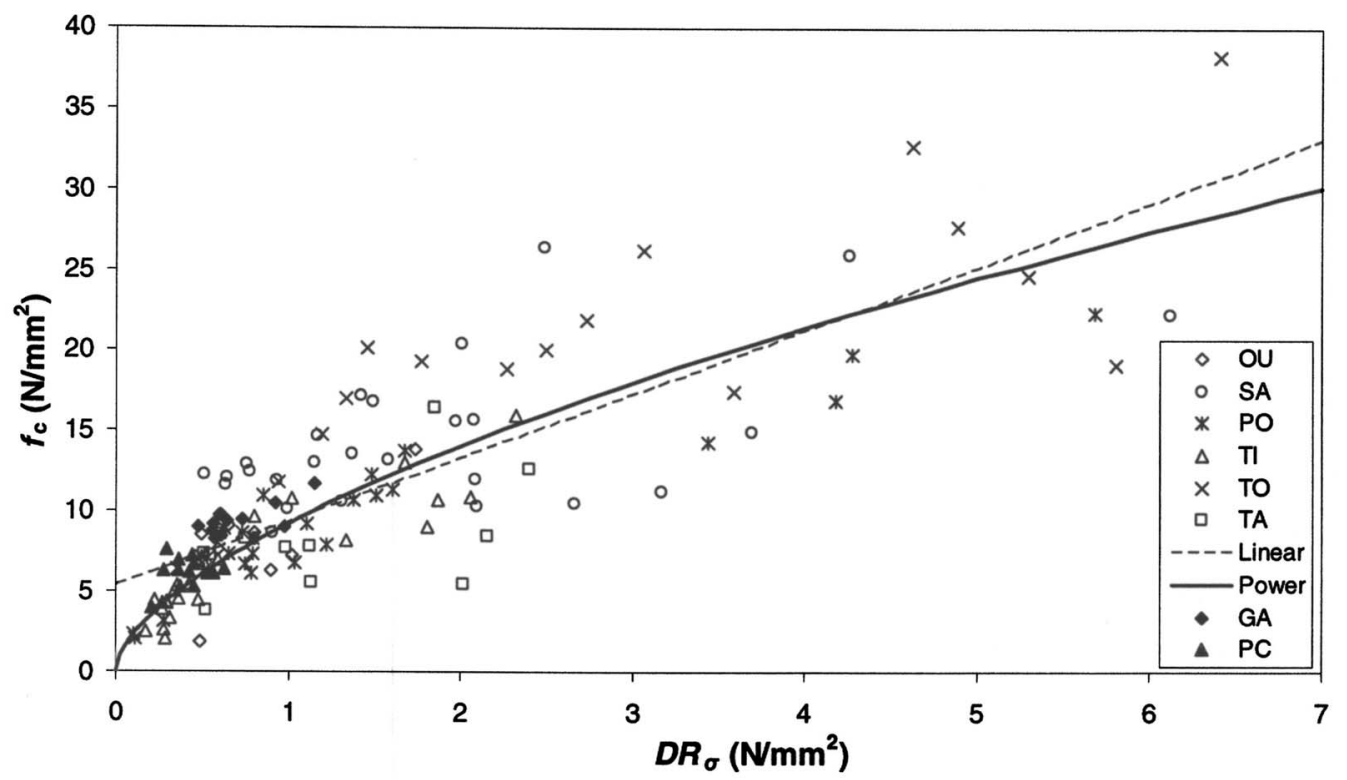

Fig. 16. Applicability of $\mathrm{DR} \sigma-f_{c}$ model for new handmade clay bricks of Alentejo, Portugal

cific weight of the bricks is comparable to the values found in old bricks (see Table 2). However, modern handmade bricks have a much lower absorption and porosity than old bricks, which is an important improvement in terms of durability.

Procedures adopted for the compression and microdrilling tests of the new bricks were the same as before. Fig. 16 presents the average pairs $\left(\mathrm{DR}_{\sigma} ; f_{c}\right)$ of the new bricks, and the correlation obtained for the old bricks. It is clear from the results that the correlation is also valid for the new bricks, although the correlation factor between the pairs $\left(\mathrm{DR}_{\sigma} ; f_{c}\right)$ from modern bricks and the model obtained from old bricks is low $\left(R^{2} \approx 0.50\right)$. Nevertheless, the modern samples are totally included in the prediction intervals with $95 \%$ of confidence calculated for the old clay brick model (see also Fig. 15).

\section{Conclusions}

An innovative methodology to assess the compressive strength of old clay bricks using nondestructive testing has been proposed. The usage of microdrilling in a large sample of bricks, from the period of the 12th to 19th century and from six different monuments allowed us to propose adequate correlations. The proposed nonlinear correlation is valid in a wide range of compressive strengths of the brick $\left(2.5-25 \mathrm{~N} / \mathrm{mm}^{2}\right)$, while the proposed linear correlation is valid only in a narrower range $\left(10-25 \mathrm{~N} / \mathrm{mm}^{2}\right.$ ). Although the scattering of the data was significant, especially for high values of $\mathrm{DR}_{\sigma}$ and $f_{c}$, the dispersion of the data was mostly contained in a prediction interval with $95 \%$ of confidence. Modern handmade traditionally fired clay bricks, used as replacement material in ancient fabric, have also been considered in the testing program. Despite the fact that these bricks exhibit a much lower porosity and water absorption than old bricks, the proposed correlations for compressive strength remain valid.

The experience of the writers indicates that: (1) the equipment used for the tests was also able to drill through high strength modern clay bricks, although the drill bit showed earlier wear; (2) the equipment was unable to drill hard stone (such as granite) due to insufficient power of the drilling motor; and (3) the pres- ence of large contents of moisture negatively affects the accuracy and the performance of this technique. The wet brick powder is expelled less efficiently and causes the drilling resistance to artificially increase.

The proposed method seems very useful to assess, with minor damage, the compressive strength of old clay bricks. But further investigation is needed, namely with respect to correlations with elastic modulus, the influence of the state of stress of the clay bricks in the drilling resistance, and a more efficient methodology to take into account the drill bit wear instead of just using a new drill as was done in this paper.

\section{Acknowledgments}

The writers gratefully acknowledge the IPPAR (Instituto Português do Património Arquitectónico) for providing the old clay bricks used in the present work. The first writer acknowledges the partial funding of this work by the FCT through Scholarship No. POCTI SFRH/BD/6409/2001.

\section{References}

Barbi, L., Briccoli Bati, S., and Ranocchiai, G. (2002). "Mechanical properties of ancient bricks: statistical analysis of data." Proc., 7th Int. Seminar on Structural Masonry for Developing Countries, Belo Horizonte, Brazil, 27-33.

Baronio, G., and Binda, L. (1985). "Physico-mechanical characteristics and durability of bricks from some monuments in Milan." Masonry International, 4, 29-35.

Bati, S., and Ranocchiai, G. (1994) "A critical review of experimental techniques for brick material." Proc., 10th Int. Brick and Block Masonry Conf., Calgary, Canada, 1247-1255.

Binda, L., Baronio, G., and Ferrieri, E. D. (1996a). "Full-scale models for the calibration of laboratory ageing tests." Proc., 7th Int. Conf. on Durability of Building Materials and Components, Stockholm, Sweden, 559-568.

Binda, L., Baronio, G., and Ferrieri, E. D. (1997). "Durability of brick 
masonry surface treatments to salt crystallization." Proc., 11th Int. Brick/Block Masonry Conf., Shanghai, China, 732-747.

Binda, L., Modena, C., and Valluzzi, M. R. (1999). "Experimental studies for the choice of repair techniques applied to historic buildings." Proc., 12th General Assembly of ICOMOS, Mexico, 1313-1322.

Binda, L., Saisi, A., and Tiraboschi, C. (2000). "Investigation procedures for the diagnosis of historic masonries." Constr. Build. Mater., 14, 199-233.

Binda, L., Tiraboschi, C., Mirabella Roberti, G., Baronio, G., and Cardani, J. (1996b). "Measuring masonry material properties: Detailed results from an extensive experimental research. Part I: Tests on masonry components." Rep. No. 5.1, Polytechnic of Milan, Milan, Italy.

Cardiano, P., Ioppolo, S., Stefano, C., Pettignano, A., Sergi, S., and Piraino, P. (2004). "Study and characterization of the ancient bricks of Monastery of "San Filippo di Fragalà" in Frazzanó (Sicily)." Anal. Chim. Acta, 519(1), 103-111.

Cultrone, G., De la Torre, M. J., Sebastian, E. M., Cazalla, O., and Rodriguez-Navarro, C. (2000). "Behavior of brick samples in aggressive environments." Water, Air, Soil Pollut., 119, 191-207.

Cultrone, G., Sebastián, E., Elert, K., de la Torre, M. J., Cazalla, O., and Rodriguez-Navarro, C. (2004). "Influence of mineralogy and firing temperature on the porosity of bricks." J. Eur. Ceram. Soc., 24, 547564.

Delgado Rodrigues, J., and Costa, D. (2004) "A new method for data correction in drill resistance tests for the effect of drill bit wear." Int. J. Restoration, 10(3), 1-18.

European Committee for Standardization (CEN). (2000). "Methods of test for masonry units. Part 1: Determination of compressive strength." EN 772-1, Brussels, Belgium.

Exadaktylos, G., Tiano, P., and Filareto, C. (2000). "Validation of a model of rotary drilling of rocks with the drilling force measurement system." Internationale Zeitschrift fur Bauinstandsetzen und Baudenkmalpflege, 6(2), 307-340.

Fairhurst, C. E., and Hudson, J. A. (1999). "Draft ISRM suggested method for the complete stress-strain curve for intact rock in uniaxial compression.” Int. J. Rock Mech. Min. Sci., 36, 279-289.

Fernandes, F. M. (2006). "Evaluation of two novel NDT techniques: microdrilling of clay bricks and ground penetrating radar in masonry." Ph.D. dissertation, Guimarães, Univ. of Minho, 〈www.civil.uminho.pt/ masonry .

International Society for Rock Mechanics Commission on Standardization of Laboratory and Field Tests (ISRM). (1978). "Suggested methods for determining the uniaxial compressive strength and deformability of rock materials." Rock characterization testing and monitoring, E. T. Brown, ed., 113-116.

Kirka, O., and Erdem, T. K. (2005). "An experimental study on the con- struction materials of the Ankara Citadel." Proc., 4th Int. Seminar on Structural Analysis of Historical Constructions, Possibilities of Numerical and Experimental Techniques, 223-229.

López-Arce, P., Garcia-Guinea, J., Gracia, M., and Obis, J. (2003). "Bricks in historical buildings of Toledo City: Characterization and restoration.” Mater. Charact., 50, 59-68.

Lourenço, P. B., Almeida, J. C., and Barros, J. A. (2005). "Experimental investigation of bricks under uniaxial tensile testing." Masonry International, 18(1), 11-20.

Lourenço, P. B., Feio, A., and Machado, J. S. (2007). "Chestnut wood in compression perpendicular to the grain: Nondestructive correlations for new and old wood." Constr. Build. Mater., 21(8), 1617-1627.

Neville, A. M. (1963). Properties of concrete, Pitman, London.

Papayianni, I., and Stefanidou, M. (2000). "Characteristics of bricks of Byzantine period." Proc., 12th Int. Brick/Block Masonry Conf., Madrid, Spain, 1729-1736.

Pauri, M., Stazi, A., Mastrosanti, F., and D’Orazio, M. (1994). "The decay of ancient building masonry, a case study." Proc., 10th Int. Brick/Block Masonry Conf., Calgary, Canada, 1295-1304.

SINT Technologies. (2001a). "Hardware manual for DRMS (HardRockMeccanica 600).” Rep. No. 836, Firenze Italy.

SINT Technologies. (2001b). "Software manual for DRMS, version 2.00." Rep. No. 834, Firenze Italy.

Tiano, P. (2001). "The use of microdrilling techniques for the characterization of stone materials. On site control and non destructive evaluation of masonry structures and materials." Proc., Int. RILEM Workshop, Italy, 1-10.

Tiano, P., et al. (2000a). "The conservation of monuments: A new method to evaluate consolidating treatments." Internationale Zeitschrift fur Bauinstandsetzen und Baudenkmalpflege, 6(2), 133-150.

Tiano, P., Filareto, C., Ponticelli, S., Ferrari, M., and Valentini, E. (2000b). "Drilling force measurement system: A new standardizable methodology to determine the stone cohesion: Prototype design and validation." Internationale Zeitschrift fur Bauinstandsetzen und Baudenkmalpflege, 6(2), 115-132.

Van Mier, J. G. M. (1984). Strain-softening of concrete under multiaxial loading conditions, Eindhoven University of Technology Press, Eindhoven, The Netherlands.

Van Vliet, M. R. A., and Van Mier, J. G. M. (1996). "Experimental investigation of concrete fracture under uniaxial compression." Mech. Cohesive-Frict. Mater., 1, 383-396.

Wijffels, T., and Nijland, T. G. (2004). "Deterioration of historic brick masonry due to combined gypsum, ettringite and thaumasite: A case study." Proc., 13th Int. Brick/Block Masonry Conf., Amsterdam, The Netherlands, 809-815. 